Subcontract NP-1

Westinghouse Astronuclear Laboratory

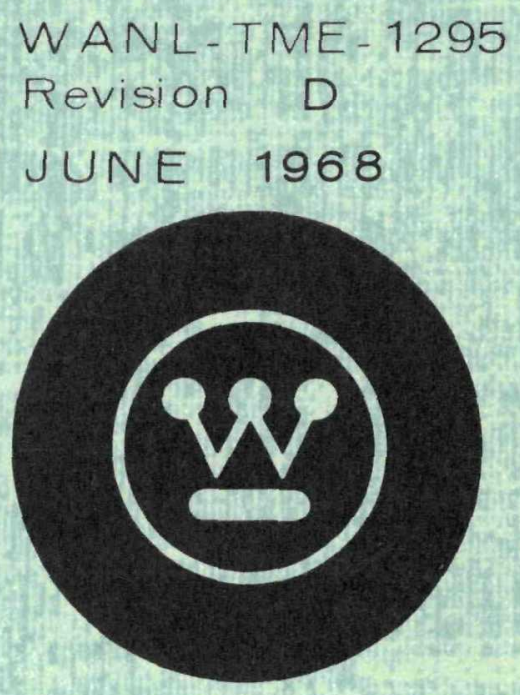

\title{
WESTINGHOUSE ASTRONUCLEAR EXPERIMENTAL FACILITY OPERATING LIMITS
}




\section{DISCLAIMER}

This report was prepared as an account of work sponsored by an agency of the United States Government. Neither the United States Government nor any agency Thereof, nor any of their employees, makes any warranty, express or implied, or assumes any legal liability or responsibility for the accuracy, completeness, or usefulness of any information, apparatus, product, or process disclosed, or represents that its use would not infringe privately owned rights. Reference herein to any specific commercial product, process, or service by trade name, trademark, manufacturer, or otherwise does not necessarily constitute or imply its endorsement, recommendation, or favoring by the United States Government or any agency thereof. The views and opinions of authors expressed herein do not necessarily state or reflect those of the United States Government or any agency thereof. 


\section{DISCLAIMER}

Portions of this document may be illegible in electronic image products. Images are produced from the best available original document. 
Subcontract NP-1

WANL-TME - 1295

Revision $D$

JUNE 1968

Westinghouse Astronuclear Laboratory

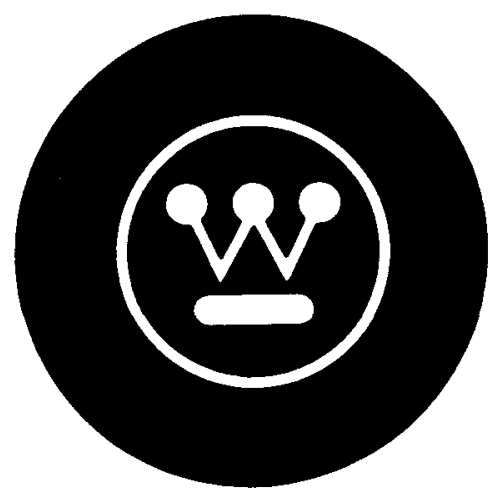

\section{WESTINGHOUSE ASTRONUCLEAR EXPERIMENTAL FACILITY OPERATING LIMITS}

Prepared By:

$\omega, H$, Williams

W. H.W illiams

Approved By:

Wellam P. Kovain

W. P. Kovacik, Manager

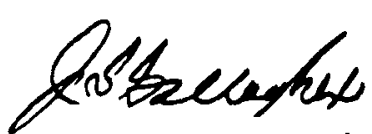

J. G. Gallagher, Manager

Thermal and Nuclear Design

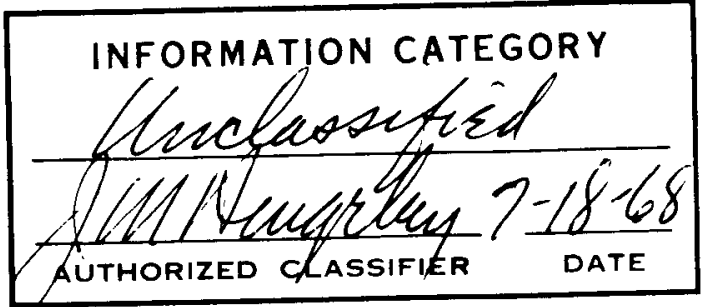

se 
W

Astronuclear

Laboratory

WANL-TME-1295

TABLE OF CONTENTS

Revision D

Section

Page

1.

Introduction .............................. 1

2. Design Specifications .................. 2- I

2.1 Reactor Description ................ 2-1

2.2 Instrumentation ...................... 2-4

2.3 Activation of Reactor Shutdown Systems ........ 2-4

2.4 Audible Devices ................ 2-5

2.5 Visual Indicators of Abnormal Operating Conditions . . . 2-5

2.6 Emergency Power Supply Availability .......... 2- 2-5

2.7 Maximum Amount of Special Nuclear Material to be Stored.. 2-8

2.8 Basic Method by Which Inadvertent Criticality is Prevented .. 2-8

2.9 Checks Which Assure that Only the Correct Reactor is

Operable from the Control Console .......... 2-8

3. Limits on Operating Variables ................. 3- .

4. Operating Procedures .................... 4-

4.1 Personnel Procedures .................. 4-1

4.2 General Operating Procedures ........... 4-3

4.3 Standard Operating Procedures ........... 4-6

4.4 Health Physics Procedures ............... 4-6

4.5 Fuel Handling and Storage Procedures .......... 4-6

4.6 Emergency Procedures ............... 4-6

5. Administrative Procedures ........................

5.1 Review and Approval Procedures ........... 5-1

5.2 Nuclear Safety Committee ............ 5-4

5.3 Periodic Inspections. ................ 5-7

6. Bibliography .............................. 
WANL-TME- 1295

Revision D

\section{INTRODUCTION}

This revision to the operating limits document has been prepared in fulfillment of Atomic Energy Commission requirements set forth in the AEC Manual Chapter 8401, "Safety of AEC-owned Reactors", for the Permanent Assembly Experiment* $(P A X)^{(1)^{* *}}$ and the Flexible Critical Experiment (FCX). Based upon the guide contained in Appendix II of AECM, Chapter 8401 approved May 7, 1965, this document supersedes the Westinghouse Astronuclear Experimental Facility Operating Limits, WANL-TME-383, issued September 23, 1963 and prior revisions to WANL-TME-1295.

In accordance with AECM 8401-044, th is operating limits document defines the boundaries with in which these AEC-owned reactors can be operated with reasonable assurance that the ir operation will not result in undue hazard. Included are those design specifications, operating variables, operating procedures and admin istrative procedures which can significantly influence safe operation and which are under the ready control of the Westinghouse Astronuclear Laboratory. Effluent discharge from the facility is limited to values set forth in AECM Chapter 0524, "Standards for Radiation Protection."

Operations will be conducted within the boundaries of this document, of WANL-

TME-267, *** WANEF Reactor Operations Manual, and within the framework of WANLTNR-099，*** Safety Report for the Westinghouse Astronuclear Experimental Facility (PAX and FCX).

*Formerly called the Pre-Assembly Experiment/Proof Test Experiment (PAX/PTX)

** References are given in the Bibliography (Section 6)

*** Latest approved issue 


\section{DESIGN SPECIFICATIONS}

\section{1 REACTOR DESCRIPTION}

\section{a. PAX}

The NRX-A reactor includes the core assembly, the outer beryllium reflector, and the lateral support. Clusters of graphite-uranium fuel elements which constitute the core assembly are held together by tie rods. Immediately surrounding the core is the lateral support or inner reflector. The beryllium reflector consists of twelve 30 -degree segments which are held between the reflector support ring and the lower support ring by through-bolts; each segment contains a rotating control drum. The PAX will have essentially the same nuclear characteristics as the NRX reactor despite modifications that will be made to the PAX assembly to simplify core changes.

\section{b. FCX}

The FCX reactor consists of fuel clusters vertically supported and located by a $1-1 / 2$ inch thick aluminum core support plate and stabilized by top-mounted hexagonal support rings. The fuel clusters are held together at both the top and bottom by means of cluster plates through which a stud is threaded into the center element. The peripheral elements are held in place by pins in the cluster plates. A reflector may be used; which may be composed of clustered elements of graphite, beryllium or other material, or it may be of other shapes with mechanical position restraints. Bare and reflected cores with various $C / U$ (65 to 300 ) ratios and void fractions will be assembled. Reactor control is provided by vertical traveling "flux trap" control rods with fuel followers. 
WANL-TME- 1295

Revision $D$

\subsubsection{Brief Description of Fuel Elements}

\section{a. PAX}

The standard NRX fuel element is a long prism with coolant holes. The fuel material is a uranium compound in a graphite matrix. The uranium is in the form of highly enriched (93\% U-235) uranium dicaride, which is coated with pyrolytic graphite. The fuel loading is less than $500 \mathrm{mg} / \mathrm{cm}^{3} \mathrm{U}$. KIWI fuel, which may be used, is similar to NRX type but does not have the pyrolytic coating.

b. FCX

The FCX reactor has been designed to utilize either reject NERVA fuel as described above, KIWI fuel or standard FCX fuel. All three types of fuel are long prisms. The standard FCX fuel contains $\mathrm{UO}_{2}$ enriched to 93 percent U-235 in a graphite matrix. The fuel loading will vary, depending on the type of fuel being used, to a maximum of $500 \mathrm{mg} / \mathrm{cm}^{3} U$. The standard FCX fuel will have the NRX fuel outer dimensions but will contain a 0.350 to 0.500 inch diameter axial hole. Insertion of either cylindrical fuel or graphite rods will be incorporated in the $F C X$ to permit a range of $C / U$ and void fractions.

2. 1.2 Maximum Total Mass of Highly Enriched Uranium in the Core

a. PAX

Less than 200 kilograms.

b. FCX

Less than 650 kilograms. 


\subsubsection{Number of Operative Control Elements and Drives Installed}

\section{a. PAX}

Twelve (eleven required)

b. FCX

Seven (four required, also see Section 3.1)

\subsubsection{Brief Description of Control Element Including Nuclear Poison Material}

\section{a. PAX}

The PAX control element is a core length beryllium cylinder to which a poison plate is fastened. The poison plates are a dispersion of elemental boron (highly enriched in the $B^{10}$ isotope) in an aluminum matrix having a nominal composition of 20 $w / O B-10$.

\section{b. FCX}

The FCX control rod is a flux trap type with a fueled follower utilizing a rod approximately twice the length of the core. The top part of the rod is a 2 inch diameter stainless steel tube which encases the absorber section of the rod. The absorber section contains a cadmium sleeve surrounding a polyethylene rod. The bottom portion of the control rod contains fueled and/or graphite elements. A long steel rod traverses the axial length of the control rod assembly and holds the internal components together in compression.

\section{1.5 Brief Description of the PAX Auxiliary Shutdown System}

The PAX Auxiliary Shutodwn System consists of hoppers connected by flexible tubes to special nozzles in the PAX core. Granules of $\mathrm{B}_{4} \mathrm{C}$ stored in the hoppers can be released by a manually activated switch at the reactor console. 
(w) Astronuclear

Laboratory

WANL-TME- 1295

Revision D

2.2 INSTRUMENTATION

2. 2. 1 Minimum Number of Operative Channels During Startup and Power

Operation

Minimum operational instrumentation shall include:

a. one source range neutron-sensitive detector and indicator with associated "flux-up" source-up interlock (minimum count rate of $120 \mathrm{cpm}$ required).

b. three neutron-sensitive detector driving amplifier systems with the capability of flux level monitoring, and including one period and three flux level scrams. The source level must be visible on one of the recorded flux level channels.

c. one gamma level detector and indicator with a gamma high level alarm.

d. a total of three pulse channels for initial criticality of new assemblies.

\subsubsection{Monitors for Radiation Level Detection'}

Monitors for radiation level detection shall include portable survey instruments in the control room, permanently installed gamma monitors in various locations, one permanently installed air monitor, excursion monitors and portable dosimetry.

2.2.3 Neutron Source

The neutron source shall be Po-Be, triple encapsulated, initially nominal 7.5 curies, and removable during operation. A source-out-of-storage indicator shall be conspicuously located in the test cell.

\subsection{ACTIVATION OF REACTOR SHUTDOWN SYSTEMS}

\subsection{Manual Activation of Shutdown Systems}

Means shall be provided for manual activation of shutdown systems, including at least one device in the test cell for the automatic systems.

\subsubsection{PAX Out-of-Reactor Position Interlocks}

A minimum of two position interlocks in series shall be used for any PAX out-of-reactor experiment which upon failure would insert more than $1.0 \$$ into the 
reactor. These interlocks shall be supported independently of the experiment and cause a reactor scram if the experiment undergoes any displacement during reactor operation.

\subsubsection{Types, Functions and Conditions of Scrams}

See Table 2-1.

\subsection{AUDIBLE DEVICES}

\subsection{Audible Indications of Source Range Multiplication}

An audible indication in the critical assembly area of source range multiplication is required for operations involving personnel in the critical assembly area. An audible indication shall also be provided in the control room.

\subsubsection{Reactor Startup Alarm}

An audible alarm system shall be available to indicate to area personnel that reactor operation is about to begin.

\subsubsection{Emergency Alarm}

A manually actuated alarm, which is capable of being heard throughout the facility, shall be available.

\subsubsection{Test Cell-to-Control Room Intercom}

A test cell area-to-control room intercommunication system shall be in operation and be of sufficient sensitivity so that communications or noise from any part of the critical assembly area which might indicate an emergency can be heard clearly in the control room.

\subsection{VISUAL INDICATORS OF ABNORMAL OPERATING CONDITIONS} See Table 2-2.

\subsection{EMERGENCY POWER SUPPLY AVAILABILITY}

Emergency power supply shall be available to provide emergency lighting, radiation monitoring, building alarm and PAX Auxiliary Shutdown System. 
TABLE 2-1

SCRAM CONDITIONS

$\underline{\text { Item }}$

Reactor Power

Reactor Power

Reactor Period

Test Cell Veto

Door Interlocks*

PAX Out-of-Reactor

Position Interlock**

Control Element Drive

"Out" Motor Current

Console

Console

\section{Actuating Means}

Electronic Trip

Electronic Trip

Electronic Trip

Manual Switch

Limit Switches

Limit Switches

Simplytrol Meter

Key Switch

Manual Switches
Actuating Signal

High power on either of two controlling linear compensated ion chamber channels.

High power level on controlling Log $N$ compensated ion chamber channel.

Short period on controlling reactor period compensated ion chamber channel.

Opened and reset manually by operating personnel. Located adjacent to the test stand in the test cell.

Opening one of the following:

$\begin{array}{ll}\text { Truck Doors } & \text { Test Cell Door } \\ \text { Yard Gates } & \text { Labyrinth Doors } \\ & \text { Emergency Exit }\end{array}$

Movement of "End-On" or "Side-by-Side" reactor experiment.

$50 \%$ overload of normal operating current for reactor in operation.

Key turned to "OFF".

Manual Activation.

* May be bypassed during checkout and maintenance. Only one control element can be moved from "Full In" position because of restrictions by mechanical locks on control elements and by electrical switches and magnet current limiting circuit.

** Used when required. See Section 2.3.2. 
(2) Astronuclear

Waboratory

WANL-TME- 1295

Revision

D

TABLE 2-2

ABNORMAL OPERATIONAL INDICATORS

Abnomal Condition

Test Cell Veto Activated

Log, Linear, or Period Tripped

Startup Channel Hi-Voltage Supply Off

Door or Fence Gate Open

Excessive Control Element Drive Current

Test Cell Basement Water Level Activated

Door Interlock Conditional Bypass Activated

PAX Auxiliary Shutdown System Power Off

PAX Out-of-Reactor Position Interlock Activated

Magnet Power not at Control Element
Indication

Red light on console

Red light on console

Red light on console

Red light on console

Red light on console

Red light on console

Yellow light above console

Amber light on console

Red light on console

Red light on console 
27 MAXIMUM AMOUNT OF SPECIAL NUCLEAR MATERIAL TO BE STORED

2.7.1 Vault $500 \mathrm{Kg} \mathrm{U}-235$

\subsection{Test Cell Rack $900 \mathrm{Kg} \mathrm{U}-235$}

\subsection{BASIC METHOD BY WHICH INADVERTENT CRITICALITY IS PREVENTED}

\subsubsection{Vault}

Vault is designed for subcriticality in either flooded or unflooded state by spacing and non-removable cadmium.

\subsubsection{Test Cell Rack}

Rack is designed for subcriticality in either flooded or unflooded state by spacing.

\subsubsection{Pax}

Reactor cover is locked during non-reactor operations; control elements are locked in least reactive position; poison shutdown wires are available, and liquids in the test cell are controlled administratively (see Section 4.2.12).

\subsubsection{FCX}

Assembly is surrounded by a fence, control elements are locked in least reactive position, and liquids in the test cell are controlled administratively (see Section 4.2.12)

\section{CHECKS WHICH ASSURE THAT ONLY THE CORRECT REACTOR IS OPERABLE FROM THE CONTROL CONSOLE}

A patch-panel interlock circuit permits control elements to be driven out only when the source transfer circuit and both patch-panels are consistent. The key-operated mechanical locks on the FCX control elements utilize the same keys as the locks on the PAX control elements. When the FCX is operated, the excess keys will be captured in the console bypass key switches. An inspection of the patch-panels for correct program board insertion is made during the daily checkout. 


\section{LIMITS ON OPERATING VARIABLES}

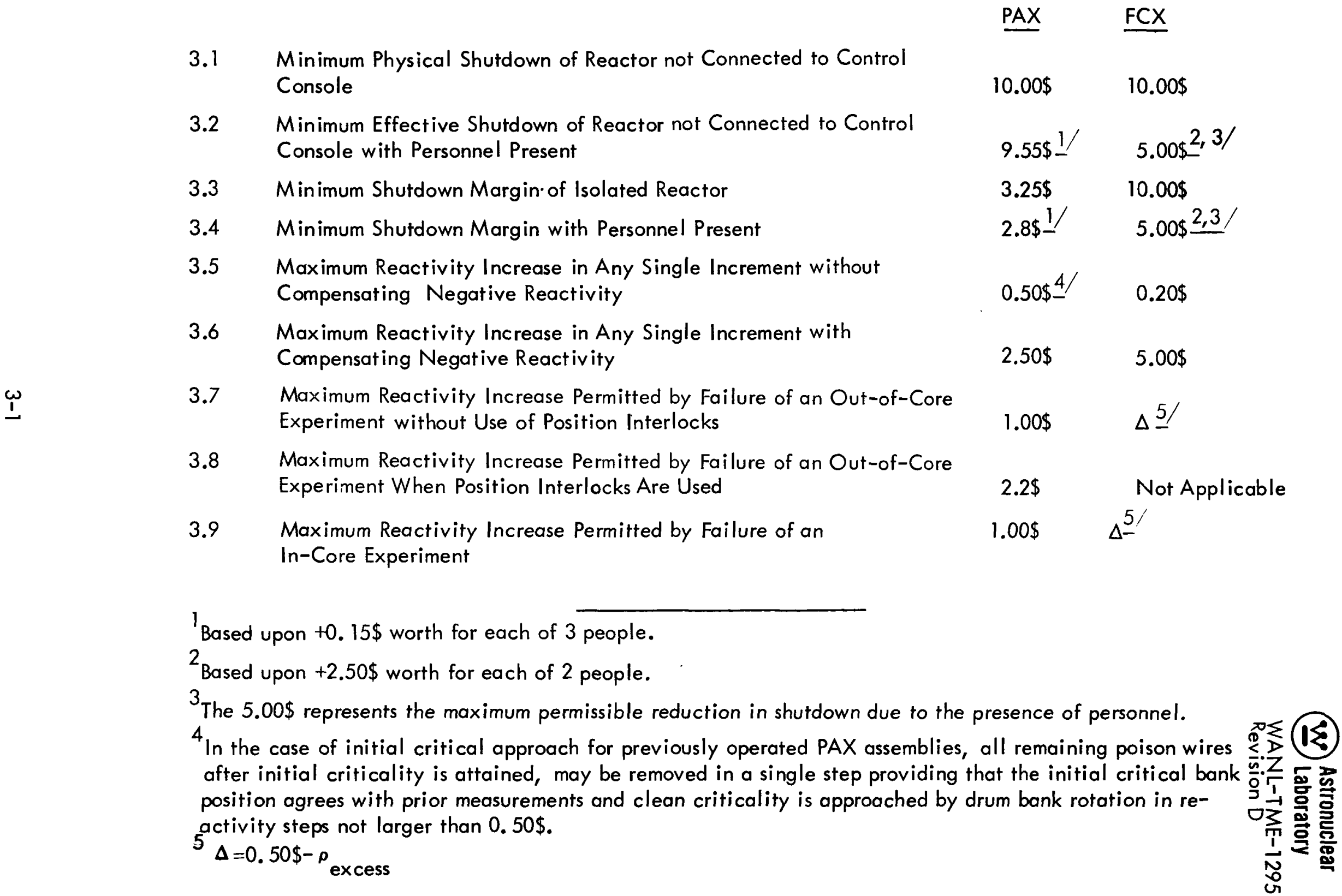


3.10 Maximum Operating Power

3.11 Maximum Power Trip Setting

3.12 Minimum Operational Period

3.13 Minimum Period Trip Setting

3.14 Maximum Excess Reactivity

3.15 Maximum Reactivity Addition Rate by Control Element

3.16 Maximum Reactivity Worth of Individual Control Element

3.17 Minimum Shutdown Control Margin in the Auxiliary Shutdown System-

3.18 Maximum Number of Control Elements To Be Moved Out at One Time

$\stackrel{\omega}{\omega}$

3.19 Minimum Number of Operational Control Elements Required

3.20 Maximum Scram Delay Time of Neutronics Safety Circuitry-

3.21 Maximum Scram Delay Time of Position Interlock Circuitry-

3.22 Average Control Drum Insertion Velacity-

3.23 Maximum Total Scram Delay and Safety Element Insertion Time

\section{PAX}

$10 \overline{00 \text { watts }}$

2000 watts

10 second

6 second

$6.2 \$$

$0.064 \$ /$ sec

$1.00 \$$

$\frac{\text { FCX }}{1000 \text { watts }}$ 2000 watts

10 second

6 second

$0.50 \$$

$0.2 \$ / \mathrm{sec}$

$5.50 \$$ central $4.00 \$$ peripheral

1.0\$ Not Applicable

1

1

114

$200 \mathrm{msec} \quad 200 \mathrm{msec}$

$150 \mathrm{msec}$ Not Applicable $500^{\circ} / \mathrm{sec} \quad$ Not Applicable

Not Applicable 1 second

${ }^{6}$ This limit shall be met in all cases except for those experiments in which the Auxiliary Shutdown System cannot be connected to the reactor. See Section 4.2, Paragraph 14 of this document.

7 Defined to be from the initiation of the scram signal to the beginning of control element motion.

${ }^{8}$ Defined to be from the initial displacement of the experiment to the beginning of control drum motion.

${ }^{9}$ Defined to be from the beginning of control drum motion to $15^{\circ}$ (beginning of shock action). 


\section{OPERATING PROCED URES}

WANL-TME- 1295

Revision D

\subsection{PERSONNEL PROCEDURES}

1) The Scientist-in-Charge must approve all experimental, operating, fuel handling, and emergency procedures before they are put into effect.

2) One Experimentalist-in-Charge will be designated by the Scientist-in-Charge to execute each critical experiment, and operating personnel will be notified of his identity.

3) All persons in the following areas are subject to the direction of the Experimentalistin-charge: Operational Areas, and the Control Room during operations.

4) A) During all critical experiments, at least two persons will be present in the control room. With the exception noted in Paragraph B below, one shall be rated equal to or greater than Reactor Operator and the other equat to or greater than Experimentalist.

B) The minimum qualification for the person at the console is that of Reactor Operator-in-Training. Under this circumstance, the second person must be rated equal to or greater than Experimentalist-in-Charge and the Reactor Operator-inTraining has demonstrated the capability of recognizing the need for and executing emergency shutdown action.

C) During all critical experiments, the Experimentalist-in-Charge will remain at WANEF.

5) There shall be a person qualified as Reactor Operator in the Control Room at all

- times when the "Master Key Switch" is $O N$ and there is a reactor in the test cell. 
6) No person is to be allowed in the test cell while changes in the critical assembly are made remotely if these changes are of a type that may credibly violate the minimum shutdown requirements given in Section 3.4.

7) The critical assembly must be shut down on demand of any member of the operating staff.

8) Personnel not part of the WANEF operating staff will take no action affecting facility operation or safety without first obtaining the permission of the Scientist-inCharge or his designated Experimentalist-in-Charge.

9) All facility personnel are required to be familiar with the facility emergency plans and equipment.

10) All experimental procedures and activities must be understood and agreed upon in advance by those persons participating in the experiment.

11) Two persons authorized and instructed by the Scientist-in-Charge must be present during the following operations:

a) when the reactivity of the reactor assembly is being changed by adding, removing, or rearranging material. One of the persons at the reactor assembly must be rated equal to or greater than Experimentalist and must inspect the critical assembly during any changes in core loading. A third person qualified as Reactor Operator must be present at the console. To ensure that the Experimentalist-in-Charge is cognizant of the type and magnitude of the change to the reactor assembly, he will sign the Manual Change Checklist prior to the change being realized.

*Daily checkout procedures with one-control element in operation permit the presence of personnel in the test cell. 
W Astronuclear

Laboratory

WANL-TME-1 295

Revision D

b) when fuel elements are being handled, assembled, or disassembled in the fuel storage and/or fuel assembly areas.

c) during any test cell activity with PAX cover removed.

12) Names of persons authorized by the Scientist-in-Charge to be contacted in emergency situations in the facility will be posted in a location that is accessible to the security guards.

13) The maximum number of personnel within three feet of the pressure vessel or the critical assembly during any test cell activity shall be approved by the Scientistin-Charge and shall be the more restrictive of (a) three persons, on (b) a number consistent with the minimum shutdown of that particular reactor.

14) The maximum number of personnel allowed in the control room at any time when the "Master Key Switch" is ON shall be four persons.

15) The Scientist-in-Charge shall shut down the reactor if operated, whenever in his judgment, conditions exist in the area of the reactor which compromise personnel safety. He will take whatever corrective action is necessary to eliminate the condition before starting up.

16) The Scientist-in-Charge shall report promptly to higher management and to AGC/SNPO any change in the physical condition of the reactor or its operating characteristics that might, in his judgment, affect the safe operation of the reactors.

17) The Scientist-in-Charge shall shutdown the reactor immediately whenever so instructed by AGC or SNPO. 
(2)

Astronuclear

Laboratory

WANL-TME- 1295

Revision D

\subsection{GENERAL OPERATING PROCEDURES}

1) Before any critical experiment is performed, the Standard Operating Procedure under which it shall be performed will have been reviewed and approved according to the procedures of Section 5. The review by the NSC will include assurance that the boundaries of operational approvals will not be exceeded.

2) Prior to and at the completion of each working day, the Experimentalist-in-Charge will inspect the test cell and reactor assemblies. Each day, prior to beginning experimental operations, satisfactory operation of all pertinent systems must be demonstrated and recorded. A daily checkout sheet will be employed and logged.

3) Each approach to critical after a major assembly change must be accompanied by neutron multiplication measurements, which can b e used to predict the points of criticality by appropriate extrapolation. During the fuel loading phase of initial criticality, a special loading source, normally located in the central region of the initial fuel loading, will be utilized.

4) Remote increases in reactivity shall be made in a safe and reversible manner wherein the rate of increase is less than the available rate of decrease.

5) Manual additions of positive reactivity can be made to the core only when the reactor is subcritical, and it has been clearly demonstrated that the reactor will remain subcritical throughout the operation.

6) Reactivity may be added in only one manner at a time. The reactivity rate of insertion for PAX must not exceed $0.064 \$ / \mathrm{sec}$ when the core is shut down by less than 2.8\$. The reactivity rate of insertion for FCX must not exceed $0.20 \$ /$ sec when the core is shutdown by less than $10.0 \$$.

7) Criticality must be attained only by the motion of control elements.

8) No core will be operated critical with a control element pattern which prevents achieving shutdown with a single control element stuck in the full out position.

9) A "key box" that may be opened only by the Scientist-in-Charge or the Experimentalists-in-Charge will be provided for storage of the following keys: 
W Astronuclear

Laboratory

WANL-TME-1 295

Revision D

a) Control console master switch

e) Fuel assembly room door

b) Control element locks (12)

f) Yard gates

c) Interlock panel door

g) Test cell personnel door

d) PAX cover locks

h) Labyrinth door

10) Keys to the control locks will be under the administrative control of the Scientistin-Charge or an Experimentalist-in-Charge at all times when not in the "key box" specified above. The keys will be given to the Experimentalist designated by the Experimentalist-in-Charge to perform an experiment or series of experiments. At the completion of reactor operations, the keys will be returned to the Experimentalist-in-Charge. When fewer than twelve control elements are operational in a reactor, the excess keys will be captured in the console bypass key switches.

11) Each component or system which affects the safety response and operation of the facility will undergo periodic (at least once annually) maintenance and calibration according to a pre-established maintenance procedure. In particular, this includes the shutdown systems, the safety and interlock circuits and radiation monitoring systems.

12) Water or other liquids are not permitted in the test cell when a reactor is present except under one of the following conditions:

1) Required liquids are used in containers and with procedures such that it will be incredible for the fluid to get into the core. The Nuclear Safefy Committee will review and recommend for approval the container design and the procedures to be used such that the incredibility of fluid getting into the core is assured. 
2) When the reactors are shut down, liquids may be used in limited amounts such that if the entire contents of the container are introduced into the core the reactivity insertion is $<1.00 \$$ in either PAX or FCX.

13) If an unanticipated reactivity change of the FCX occurs on a day-to-day basis, as evidenced by a corresponding change in rod bank and/or period measurements which exceeds $0.20 \$$, the reactor shall be shut down and the EIC notified and the situation evaluated. Attention is called to the fact that a change less than $0.20 \$$ will require reactor shutdown if the limit on $k_{\text {excess }}$ is exceeded.

14) Prior to any PAX reactor operations, at least one of the PAX Auxiliary Shutdown System (PASS) hoses shall be connected to the PAX. Experiments for which the PASS hoses cannot be physically connected to the reactor will be performed accardance with SPO 5.5.8 as contained in the latest revision of the WANEF Reactor Operations Manual (Chapter $5^{(2)} \lambda$ The PAX reactor shall not be started up (or, if operating, shall be shutdown) when the console light indicates insufficient power available for PASS operation.

\subsection{STAND ARD OPERATING PROCEDURES}

Standard Operating Procedures (SOP) for the routine operation of the reactors and the operation of the facility are contained in and are a part of the Reactor Operations Manual (Chapter 5) $^{(2)}$.

\subsection{HEALTH PHYSICS PROCEDURES}

Health Physics procedures used at WANEF are those of the Waltz Mill Site ${ }^{(3)}$. They will be approved for use at WANEF by the Scientist-in-Charge.

\subsection{FUEL HANDLING AND STORAGE PROCEDURES}

Fuel handling and storage procedures are contained in the Nuclear Safety Manual ${ }^{(4)}$.

\subsection{EMERGENCY PROCEDURES}

Emergency plans and procedures to be employed at WANEF are set forth in Section 5.9 of the Reactor Operations Manual ${ }^{(2)}$. Emergency plans and procedures exist for the Waltz Mill Site ${ }^{(5)}$. 


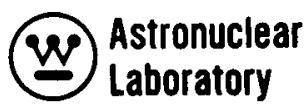

WANL-TME-1295

Revision D

\section{ADMINISTRATIVE PROCEDURES}

Administrative controls important to safety in the operation of WANEF critical assemblies include review and approval procedures of controlling documents, experimental procedures, fuel handling procedures, and the composition and reviews of the Nuclear Safety Committee. Also included are the review and approval procedures for changes to the reactors, test stands, and facility.

\subsection{REVIEW AND APPROVAL PROCEDURES}

\subsubsection{Review and Approval Procedures for Controlling Documents}

Changes and addenda to this operating limits document and the supporting changes and addenda to the Safety Report must be reviewed by the Nuclear Safety Committee (NSC) and then together with the necessary supporting analysis referred to the Aerojet-General Corporation (AGC) and the Space Nuclear Propulsion Office (SNPO) with a request for approval.

\subsubsection{Review and Approval Procedures for the Reactor Operations Manual}

Changes to the Reactor Operations Manual which deviate from the limits specified in this document or from the intent of the currently approved Reactor Operations Manual must be reviewed by the Nuclear Safety Committee (NSC) and then together with the necessary supporting analysis referred to the Aerojet-General Corporation (AGC) and the Space Nuclear Propulsion Office (SNPO) with a request for approval.

Changes to the Reactor Operations Manual which do not change the intent of the currently approved Reactor Operations Manual, do not exceed the limits of this document, do not introduce the possibility of an accident not analyzed in the Safety Report, and do not increase the probability or the consequences of any accident analyzed in the Safety Report or 
its supplements must be reviewed by the NSC and recommended by them for approval to the

Project Manager. Recommendations for approval for such changes in the Reactor Operations Manual may be made to the Project Manager by an appointed subcommittee of the NSC providing that the decision is unanimous and all action is documented and submitted to the Chairman of the NSC.

Copies of all changes and revisions to the Reactor Operations Manual will be sent to AGC and SNPO-C.

\subsubsection{Review and Approval Procedures for Experimental Procedures}

Experimental procedures at WANEF are of two types: 1) Standard Operating Procedures (SOP) which are contained in and are a part of Reactor Operations Manual (Chapter 5), and 2) the Experimental Details Checklist (EDC). The review and approval procedures as specified above for the Reactor Operations Manual apply to the Standard Operating Procedures. In contrast to the SOP which are generalized experimental procedures, an EDC is prepared for a particular experiment. It describes the materials required, the hazards involved and the methods used to minimize them, the experimental procedure to be employed and the data required to successfully complete the experiment. It must be reviewed and recommended for approval by the Scientist-in-Charge (SIC). If the Manager, Thermal and Nuclear Design, decides that it is within the limits of this document, and is consistent with portions of one or more SOP's in the Reactor Operations Manual and does not involve either unevaluated questions of safety* or operations which are expected to exceed the radiation exposure limits (AEC Manual Chapter 0524), then he will approve it and send information copies to cognizant

*Unevaluated questions of safety exist if 1) there is a possibility of an accident occurring which has not been analyzed in the WANEF Safety Report or its Supplements, or if 2) there is an increase in either the probability of an accident previously analyzed or if 3 ) there is an increase in the consequences of an accident previously analyzed. 
(2) Astronuclear

WANL-TME-1295

Revision D

non-line personnel. If it does not fall clearly into this category, he must submit it to the NSC for review and a determination will be made as to whether or not it does fall into the above category. If the NSC finds that it does fall into the category, it will recommend for approval to the Project Manager. If the NSC finds, however, that it does not fall into the above category, a description of the experiment will be submitted to AGC and SNPO with a request for approval. The approval request will include a supporting safety analysis and/or a description of the appropriate engineered safeguards.

\subsubsection{Review and approval Procedures for Fuel Handling Procedures}

No changes in existing procedures may be made without the written approval of the Nuclear Safety Engineer and one permanent member of the NSC. They must examine the pruposed changes and determine whether they fall with in the intent of the Nuclear Safety Manual $^{(4)}$. If so, the Nuclear Safety Engineer and one permanent member of the NSC will recommend approval in writing to the line manager who originally approved the governing Nuclear Safety Manual with an information copy to the NSC. Proposed changes which do not fall within the intent of the Nuclear Safety Manual or the ground rules of the Criticality Hazards Confrol Guide ${ }^{(6)}$ or any change which they decide to so refer, will be referred to the NSC for consideration.

\subsubsection{Review and Approval Procedures for Reactor Changes}

Those changes for the reactor as required by the experimental program will be conducted within the framework of the SOP and EDC as described in 5.1.3 and will be governed by the restrictions stated therein. Other changes as required for maintenance or operational reasons, if judged by the SIC to be with in the limits of this document and do not constitute an unevaluated safety question, will be (1) approved by the Scientist-in-Charge and 
Revision D

(2) concurred with by the Manager of Thermal and Nuclear Design. All significant changes will be reported to AGC/SNPO in the WANEF Annual Operations Report.

Changes that do not clearly fall within the limits of this document or may represent an unevaluated safety question will be submitted to the NSC for review and a determination will be made as to whether or not it does fall within the limits of this document and does not represent an unevaluated safety question. If the NSC finds that the change lies within the limits of this document and does not represent an unevaluated safety question, the NSC will recommend approval to the Project Manager. If the change does not fall within the limits of this document or represents an unevaluated safety question, the change will be submitted to AGC and SNPO for approval.

\subsubsection{Review and Approval Procedure for Changes to the Test Stands and the Facility}

Changes to the reactor test stands and the facility will be (1) approved by the Scientist-in-Charge and (2) concurred with by the Manager of Thermal and Nuclear Design if such changes are judged by the SIC to be within the limits of this document and do not represent an unevaluated safety question. All significant changes will be reported to AGC/SNPO in the WANEF Operations Report.

Changes that do not clearly fall within the limits of this document or may represent an unevaluated safety question will be handled as in Section 5.1.5.

\subsection{NUCLEAR SAFETY COMMITTEE}

\subsubsection{General}

The WANL Nuclear Safety Committee is established to advise the Project Manager on matters of nuclear safety. It shall review and consult on all major problems concerned with the nuclear safety of the WANEF facility. The Committee, whose quali- 
(2) Astronuclear

WANL-TME- 1295

Revision D

fications are listed below, is composed of senior personnel knowledgeable in the various technical and scientific areas pertinent to the WANEF operation.

\subsubsection{Membership}

\section{(1) Permanent Chairman}

The permanent chairman must be a management level Westinghouse employe with at least ten years professional experience including at least five years in close association with the nuclear industry. An alternate will be designated from among the permanent membership.

(2) Permanent Member (3-5)

Permanent members must have at least five years professional industrial experience including three years of active participation in applied nuclear work. At least one member must represent a major competence in reactor physics, and at least one member must represent major competence in nuclear safety.

(3) Temporary Member

Temporary members of the Committee for WANEF reviews will include a member of the WREC* staff, a nuclear consultant from an independent organization, and the Scientist-in-Charge.

\section{(4) Ex-Officio}

For special problems, additional non-permanent members may be authorized by the Nuclear Safety Committee to serve in consultant capacity or on such subcommittees as may be required.

\section{(5) Secretary}

* Westinghouse Reactor Evaluation Center (WARD) 
We Astronuclear
Waboratory

Revision D

The secretary must be a person qualified to extract and record the essence and conclusion of the committee discussions. One of the above committee members may act as the Secretary.

\subsubsection{Responsibilities}

It is the responsibility of the Committee to review all experimental programs together with supporting safety analyses, operating procedures, and proposed modifications to the operating limits and to system or facility designs which may affect or change the safety of the facility operation. The review will also include an assurance that boundaries of operational approvals will not be exceeded. Upon completion of a review, the Comm ittee will submit a report to the Project Manager. Those items which have been favorably reviewed will be recommended for approval to the Project Manager or submitted to AGC/SNPO for approval according to the Review and Approval Procedure requirements of Section 5.1. Copies of the report will be sent to the appropriate Manager and Supervisors concerned with the WANEF operation. In most cases, the report will take the form of the minutes of the Nuclear Safety meeting and indicate the Committee's decision concerning the changes or operations. The reviews to be conducted by the Committee may take several forms. These are listed below:

\section{(1) Regular Meetings}

A regularly scheduled meeting of the Nuclear Safety Committee will be held to review the proposed experimental plans to be employed in the next six-month period. This meeting will be used to review any major modifications to be made in the facility design.

(2) Special Meetings

Special meetings of the Nuclear Safety Committee can be called by the 
QS Astronuclear

Laboratory

WANL-TME- 1295

Revision D

Chairman or Alternate Chairman at any time he feels that additional special reviews are necessary. These reviews can also be requested by the Scientist-in-Charge at any time he feels that a review of a modification and/or operation is required.

\section{(3) Telephone Survey}

In some cases, as determined by the Committee Chaiman, the formality of calling a Committee meeting to review an experimental procedure or modification is not necessary. Instead, the required information can be forwarded to the Committee members and, after the individual members review the proposed change, the Chairman can make a telephone survey to obtain their reactions to the change. In the event any committee member considers the subject of sufficient significance, he may request that a committee meeting be held.

\subsection{PERIODIC INSPECTIONS}

Periodic inspections by competent technical personnel outside of the WANEF line organization will be made of WANEF operations to assure conformance to the established nuclear safety requirements. Particular attention will be paid to reactor performance and the training and qualifications of operating and maintenance personnel. A report of these inspections will be forwarded to the member of line management next above the Manager, Thermal and Nuclear Design, who will be responsible for any corrective action. 


\section{BIBLIOGRAPHY}

1 WANL-TNR-099, Revision B, Safety Report for the Westinghouse Astronuclear Experimental Facility, (PAX and FCX), June 1968

2 WANL-TME-267, Revision G, WANEF Reactor Operations Manual, June 1968

3 WCAP-2034, Health Physics Manual, Westinghouse Atomic Power Division, Waltz Mill Site, March 1961, Revised May 1963

4 WANL-TME-646, Revision C, Westinghouse Astronuclear Experimental Facility (WANEF) Nuclear Safety Manual, April 1968

5 a. WCAP-2576, Emergency Procedures for Waltz Mill Site

b. WCAP-2712, Medical Radiation Emergency Procedures

c. Waltz Mill Site Emergency Health Physics Team Procedures

6 WANL-TME-185, Westinghouse Astronuclear Laboratory Criticality Hazards Control Guide, November 1962 